\title{
MODELLING NET PHOTOSYNTHETIC RATE OF TEMPERATE DRY GRASSLAND SPECIES AND WINTER WHEAT AT ELEVATED AIR $\mathrm{CO}_{2}$ CONCENTRATION
}

\author{
N. HARNOS ${ }^{1} *$ - Z. NAGY ${ }^{2}$ - J. BALOGH ${ }^{2}-$ Z. TUBA ${ }^{2}$ \\ ${ }^{1}$ Agricultural Research Institute of the Hungarian Academy of Sciences \\ P.O.Box 19. H-2462, Martonvásár, Hungary \\ (phone: +36-22-569-508) \\ ${ }^{2}$ Department of Botany and Plant Physiology, Fac. Agric. Env. Sci., St. István University \\ Páter K. u. 1., H-2103, Gödöllö, Hungary \\ (phone: +36-28-522-075) \\ *e-mail: noemi@mail.mgki.hu \\ (Received $10^{\text {th }}$ Sep 2005, accepted $10^{\text {th }}$ Oct 2006)
}

\begin{abstract}
A number of $\mathrm{C}_{3}$ temperate dry grassland species and winter wheat plants were grown in open top chambers either at $365 \mu \mathrm{mol} \mathrm{mol}^{-1}$ (AC) or at $700 \mu \mathrm{mol} \mathrm{mol}^{-1}$ (EC) air $\mathrm{CO}_{2}$ concentrations. Gas exchange measurements were made at several air $\mathrm{CO}_{2}$ concentrations. When measured at higher $\mathrm{CO}_{2}$ concentrations, net photosynthetic rate was higher in plants grown at EC than at AC. The widely accepted Farquhar net photosynthesis model was parameterized and tested using several observed data. After parameterization the test results corresponded satisfactorily with observed values under several environmental conditions.
\end{abstract}

Keywords: temperate grasses, winter wheat, photosynthesis, modelling

\section{Introduction}

Many authors use simulation models, in addition to experimental work, to describe plant development and plant production responses to several environmental factors such as higher temperature, drought stress and elevated air $\mathrm{CO}_{2}$ concentrations (EC). Simulation models describing carbon balance of leaves, whole plants, and ecosystems use a biochemical model of the net photosynthetic rate $\left(P_{\mathrm{N}}\right)$. The most popular model is the biochemical model of Farquhar et al. (1980), Farquhar and Caemmerer (1982), and their modified versions [9, 4]. In general, the parameterization of a simulation model is not an easy task. Most plants respond to their environment in different ways. As a result, parameter values may differ depending on the plant species and possibly even the plant variety being used. Simulation models are important for describing the effects of EC on photosynthesis. They allow $P_{\mathrm{N}}$ to be predicted without having to carry out measurements.

Abbreviations: $\mathrm{AC}=$ ambient $\left[\mathrm{CO}_{2}\right] ;\left[\mathrm{CO}_{2}\right]=$ air $\mathrm{CO}_{2}$ concentration; $C_{\mathrm{i}}=$ partial pressure of $\mathrm{CO}_{2}$ in the intercellular space; $\mathrm{EC}=$ elevated $\left[\mathrm{CO}_{2}\right] ; \mathrm{M}=$ average deviation; $\mathrm{OTC}=$ open top chamber; $P_{\mathrm{N}}=$ net photosynthetic rate; $r^{2}=$ determination coefficient. 


\section{Materials and methods}

\section{Plants and $\mathrm{CO}_{2}$ fumigation}

The experiments were carried out in perspex open top chambers (OTC) $(130 \mathrm{~cm}$ in diameter and $100 \mathrm{~cm}$ in height) at the Global Climate Change and Plant Research Station in Gödöllö, Hungary. The climate of the region is temperate-continental with hot, dry summers. The annual mean temperature is $11^{\circ} \mathrm{C}$ and the annual precipitation is $500 \mathrm{~mm}$. $\left[\mathrm{CO}_{2}\right]$ was kept at the present-day concentration, $\mathrm{AC}\left(365 \mu \mathrm{mol} \mathrm{mol}{ }^{-1}\right)$ for the control and at $700 \mu \mathrm{mol} \mathrm{mol}{ }^{-1}$ for the EC treatment. The plants were occasionally irrigated as needed and weed control was carried out mechanically.

\section{Winter wheat}

Seeds of winter wheat (Triticum aestivum L.) were sown in OTC in two different years with two cultivars (cv. Emma in the first and cv. Martonvásári 15, MV-15) in the second experiment) $[5,11]$. The seed spacing was $13.0 \times 1.5 \mathrm{~cm}$. The soil was a light moderately calcareous sandy soil. N,P and K fertilisers were applied at rates of 10, 5 and $5 \mathrm{~g} \mathrm{~m}-2(100,50$, and $50 \mathrm{~kg}$ ha-1), respectively before sowing.

\section{Grassland}

The studied vegetation was a xeric temperate loess steppe situated on the edge of the Hungarian Great Plain [8]. The parent rock was sandy loess or loess with thick humus and a nutrient-rich A horizon. The original grassland was made up of more than 90

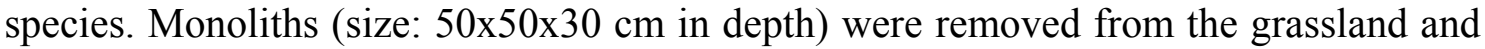
transplanted into the open top chambers with four monoliths to a chamber. The soil in the chambers was removed and replaced by soil from the profiles the monoliths had been collected from. Four weeks after transplantation the grass was cut. Following a two-month adaptation period, the monoliths in the EC chambers were gradually exposed, over a 4-week period, to $700 \mu \mathrm{mol} \mathrm{mol}^{-1}\left[\mathrm{CO}_{2}\right]$. The species studied during the 3 -year exposure to EC and AC were the monocot Festuca rupicola Heuff. and the dicot Filipendula vulgaris Mönch. F. rupicola, the dominant species of the grassland, has sclerenchymatous erect leaves with a waxy surface, while $F$. vulgaris has soft, large incised leaves. Both species are perennial and have $\mathrm{C}_{3}$ photosynthesis.

\section{Measurements}

The $C_{\mathrm{i}}$ dependence of light-saturated $P_{\mathrm{N}}\left(P_{\mathrm{N}} / C_{\mathrm{i}}\right.$ curves $)$ was measured in the flag leaves of winter wheat at the beginning of flowering and on the grassland species $F$. rupicola and $F$. vulgaris two and 36 months after the beginning of exposition. Measurements were made using an LCA2-type IRGA system ( $A D C$, Hoddesdon, UK), operated in differential mode and a Parkinson $L C-N$ leaf chamber with an airflow of 5 $\mathrm{cm}^{3} \mathrm{~s}^{-1} .\left[\mathrm{CO}_{2}\right]$ values of $30,100,200,330,540,730$ and $900 \mu \mathrm{mol} \mathrm{mol}^{-1}$ were produced using a gas diluter ( $G D$ 600, $A D C$, Hoddesdon, UK). The photosynthetically active radiation (PAR) and the leaf surface temperature were kept constant at $1000 \pm 100 \mu \mathrm{mol}$ $\mathrm{m}^{-2} \mathrm{~s}^{-1}$ and $20.5 \pm 1.5^{\circ} \mathrm{C}$ for winter wheat cv. Emma, $800 \pm 100 \mu \mathrm{mol} \mathrm{m} \mathrm{m}^{-2} \mathrm{~s}^{-1}$ and $20 \pm 1{ }^{\circ} \mathrm{C}$ for winter wheat cv. MV-15 and $1200 \mu \mathrm{mol} \mathrm{m} \mathrm{s}^{-2}$ and $23 \pm 1.5^{\circ} \mathrm{C}$ for grassland. 


\section{Farquhar model}

The gas exchange measurements were used to set the parameters and validate the biochemical model described by Farquhar et al. (1980) and Farquhar and Caemmerer (1982), and the modified version elaborated by Sharkey (1985) and Harley and Sharkey (1991) (referred to as the Farquhar model in this work).

$P_{\mathrm{N}}$ can be expressed by the Farquhar model (for detailed description, see Appendix):

$$
P_{\mathrm{N}}=V_{\mathrm{c}}-0.5 V_{\mathrm{o}}-R_{\text {day }}=V_{\mathrm{c}}\left(1-\frac{0.5 O_{\mathrm{i}}}{\tau \cdot C_{\mathrm{i}}}\right)-R_{\text {day }},
$$

where the rate of carboxylation, $V_{\mathrm{c}}$, is assumed to be limited by one of three factors: the activation state and kinetic properties of Rubisco, the regeneration of RuBP in the Calvin cycle, or the rate of phosphate release during triose phosphate utilization (starch and sucrose production). The micrometeorological variables included temperature, irradiance and $\left[\mathrm{CO}_{2}\right]$, which were measured and calculated with the IRGA equipment. Determination coefficients $\left(r^{2}\right)$ were calculated to compare and analyze the relationship between observed and simulated $P_{\mathrm{N}}$, and average deviation (M) to calculate the difference between observed and simulated $P_{\mathrm{N}}$.

\section{Results}

The parameterization of the Farquhar model was performed on winter wheat $\mathrm{cv}$. Emma, using $P_{\mathrm{N}}$ measurements on flag leaves at seven different air $\mathrm{CO}_{2}$ concentrations at the beginning of flowering for plants grown at AC or EC. After parameterization, the Farquhar model gave a good estimation of the $P_{\mathrm{N}}$ of winter wheat cv. Emma in both treatments (Fig. $1 \mathrm{~A}$ ). The determination coefficients and average deviation between observed and simulated net photosynthetic rates were $r^{2}=0.9, \mathrm{M}=0.98$ for plants grown at $\mathrm{AC}$ and $r^{2}=0.98, \mathrm{M}=0.34$ for plants grown at $\mathrm{EC}$. The simulation results were not affected by irradiation because of the light saturated conditions. In both treatments $P_{\mathrm{N}}$ was limited by the rate of phosphate release during triose phosphate utilization at higher $\left[\mathrm{CO}_{2}\right]$. The $\mathrm{CO}_{2}$ saturation concentration and the saturated $P_{\mathrm{N}}$ were smaller for $\mathrm{AC}$ plants than at EC.

To validate the model the data set from the other experiment was used. Using the same parameter values as in the first experiment the model simulated $P_{\mathrm{N}}$ accurately, as shown by the $r^{2}$ and $\mathrm{M}$ values in Fig. $1 \mathrm{~B}$. 

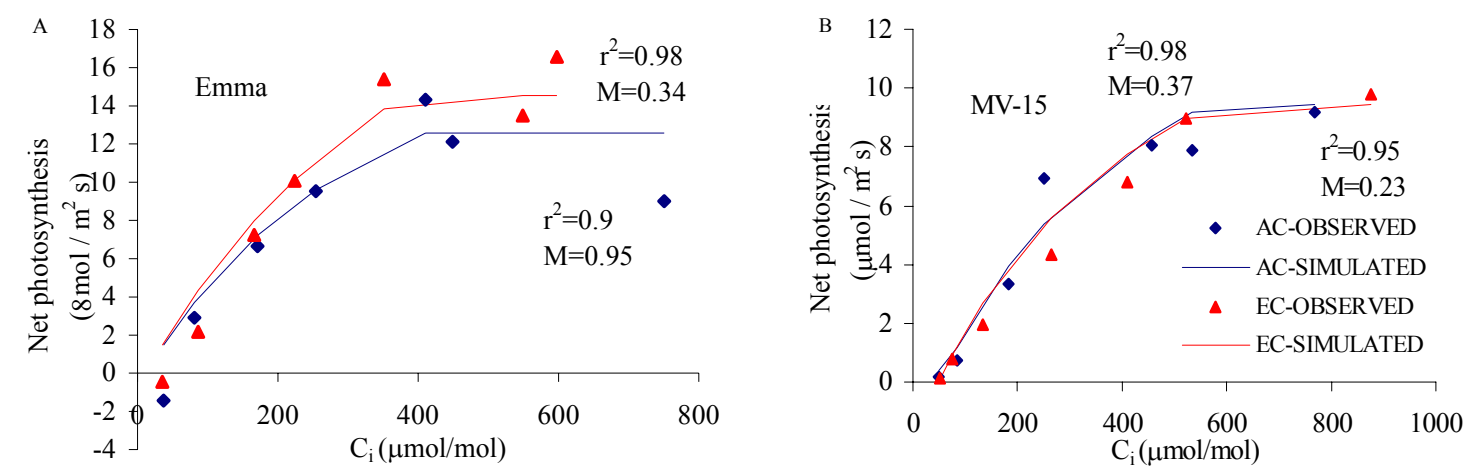

Figure 1. Measured and simulated net photosynthetic rate of flag leaves of winter wheat (c. Emma $A, M V-15$ B) grown from germination at ambient, $\mathrm{AC}$ (control), or enhanced, $E C \mathrm{CO}_{2}$ concentration. $\mathrm{r}^{2}$ denotes determination coefficient and $M$ denotes average deviation between observed and simulated values.

The acclimation of $P_{\mathrm{N}}$ to EC varied both between species and over the course of the period of exposure. After two months of exposure upward acclimation was exhibited by all EC plants, the degree of which was greater in the dicot species. After 36 months of exposure the monocot species $F$. rupicola showed a downward acclimation in Rubisco capacity and its $P_{\mathrm{N}} / \mathrm{C}_{\mathrm{i}}$ curve did not reach saturation. The dicot species $F$. vulgaris showed upregulation for both Rubisco capacity and RuBP regeneration capacity.

Simulations were done for both grassland species studied. The parameter values used in the model were set the same after two and 36 months of $\mathrm{CO}_{2}$ exposure but differed in the two species. The model simulated $P_{N}$ accurately in all cases when the plants were grown at $\mathrm{AC}$ (for both species and after both exposure times). After two months of exposure the model did not adequately simulate $P_{N}$ when the plants were grown at EC, but after 36 months the simulation results were accurate.
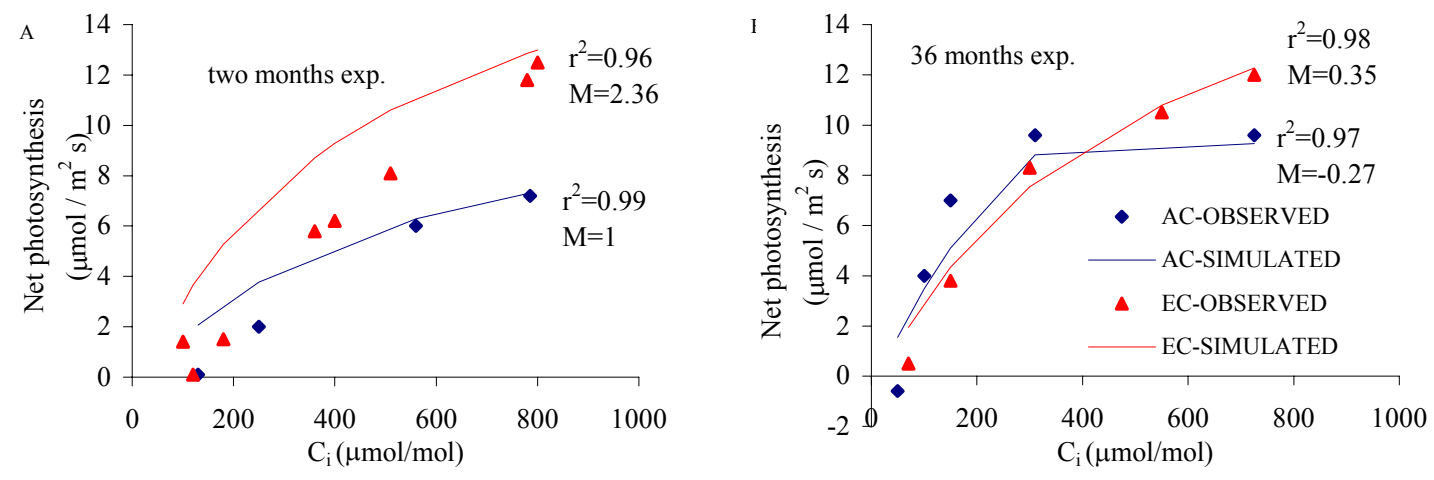

Figure 2. Measured and simulated net photosynthetic rate of leaves of $F$. rupicola grown at $A C$ or at EC after two (A) or $36(B)$ months of exposure. $r^{2}$ denotes determination coefficient and $M$ denotes average deviation between observed and simulated values. 

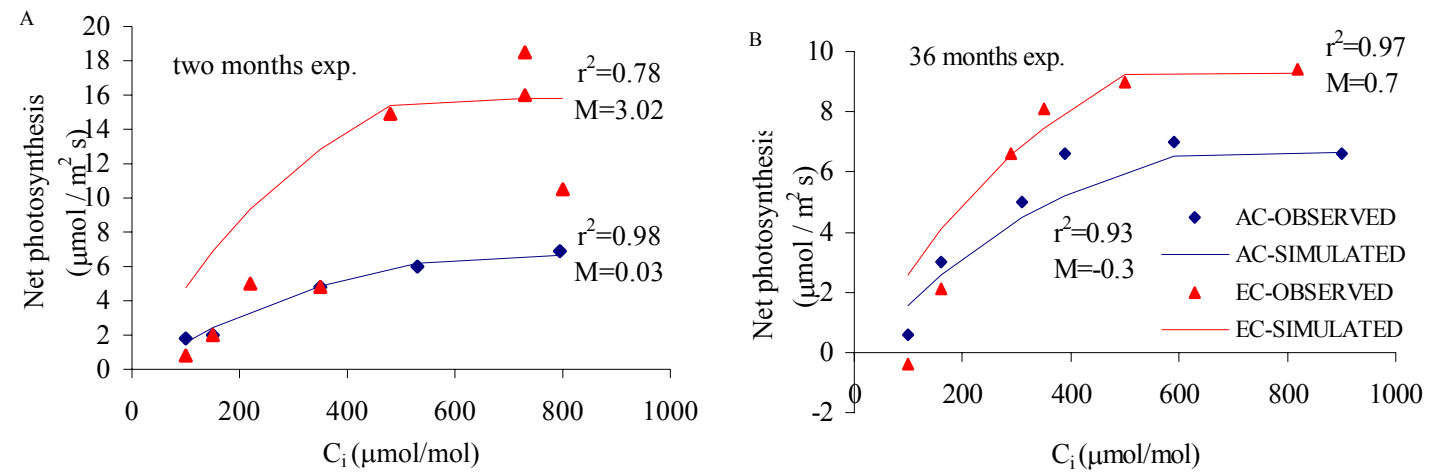

Figure 3. Measured and simulated net photosynthetic rate of leaves of $F$. vulgaris grown at AC or at EC after two (A) or $36(B)$ months of exposure. $r 2$ denotes determination coefficient and $M$ denotes average deviation between observed and simulated values.

\section{Discussion}

The aim of the experiment was to obtain information on how the model of Farquhar et al. (1980) and Farquhar and Caemmerer (1982) modified by Sharkey (1985) and Harley and Sharkey (1991), described the $P_{\mathrm{N}}$ of Hungarian winter wheat cultivars and grassland species. The results of $P_{\mathrm{N}}$ measurements revealed two important facts: first, there was a large increase in $P_{\mathrm{N}}$ as a result of EC, and second, gas exchange acclimation responses were influenced by the length of exposure to EC.

The study also supports the use of the model for describing the $P_{\mathrm{N}}$ of various $\mathrm{C}_{3}$ plants under several types of environmental conditions. Separate parameterization and validation for individual plant species is essential, but the results show that the same parameterization can be used for two different Hungarian winter wheat cultivars grown in different years.

In conclusion, the Farquhar model is able to describe the $P_{\mathrm{N}}$ of different plant species under various environmental conditions (irradiance, temperature, $\mathrm{CO}_{2}$ ), but parameterization has to be done very carefully in all cases, especially for long-term examinations. Hence, the Farquhar model should be included in various plant growth simulation models.

Acknowledgements. The present study was carried out in the framework of the ESPACE-Grass Project (EU Brussels Contract No. EV5V-CT93-0292) and was supported by the ECOCRAFT Environment R\&D Programme (EU Brussels), by the MEGARICH Project, EU contract ENV4-CT97-0503, the Hungarian Scientific Research Fund (OTKA, Nos. F020704, T18595, T22723), and the Research Development of Higher Education (FKFP0472/97).

\section{REFERENCES}

[1] Brooks, A., Farquhar, G.D. (1985): Effect of temperature on the $\mathrm{CO}_{2} / \mathrm{O}_{2}$ specificity of ribulose-1,5-bisphosphate carboxylase/oxygenase and the rate of respiration in the light: estimates from gas-exchange experiments on spinach. - Planta 165: 397-406. 
[2] Farquhar, G.D., von Caemmerer, S. (1982): Modelling of photosynthetic response to environmental conditions. - In: Lange, O.L., Nobel, P.S., Osmond, C.B., Ziegler, H., (Szerk.): Physiological plant ecology II. Water relations and carbon assimilation. Encyclopedia of plant physiology, New series, Berlin: Springer-Verlag, Vol. 12B. 549587. p.

[3] Farquhar, G.D., von Caemmerer, S., Berry J.A. (1980): A biochemical model of photosynthetic $\mathrm{CO}_{2}$ assimilation in leaves of $\mathrm{C}_{3}$ species. - Planta 149: 78-90.

[4] Harley, P.C., Sharkey, T.D. (1991): An improved model of $\mathrm{C}_{3}$ photosynthesis at high $\mathrm{CO}_{2}$ : Reversed $\mathrm{O}_{2}$ sensitivity explained by lack of glycerate re-entry into the chloroplast. - Photosynthesis Research 27: 169-178.

[5] Harnos, N., Tuba, Z., Szente, K. (2002): Modelling net photosynthetic rate of winter wheat in elevated air $\mathrm{CO}_{2}$ concentrations. - Photosynthetica 40(2): 293-300.

[6] Johnson, F., Eyring, H., Williams, R., (1942): The nature of enzyme inhibitions in bacterial luminescence: sulfanilamide, urethane, temperature and pressure. - Journal of Cell Comparative Physiology 20: 247-268.

[7] Jordan, D.B., Orgen, W.L. (1984): The $\mathrm{CO}_{2} / \mathrm{O}_{2}$ specificity of ribulose 1,5-bisphosphate carboxylase/oxygenase: dependence on ribulose-bisphosphate concentration, $\mathrm{pH}$ and temperature. - Planta 161: 308-313.

[8] Nagy, Z., Szente, K., Tuba, Z. (1997): Acclimation of dicot and monocot temperate grassland species to long-term elevated $\mathrm{CO}_{2}$ concentration. - Abstracta Botanica 21(2): 297-304.

[9] Sharkey, T.D. (1985): Photosynthesis in intact leaves of $C_{3}$ plants: Physics, physiology and rate limitations. - The Botanical Review 51: 53-105.

[10] Smith, E. (1937): The influence of light and carbon dioxide on photosynthesis. - General Physiology 20: 807-830.

[11] Tuba Z., Szente K., Koch J. (1994): Response of photosynthesis, stomatal conductance, water use efficiency and production to long-term elevated $\mathrm{CO}_{2}$ in winter wheat. - Journal of Plant Physiology 144 (6): 669-678.

\section{Appendix}

\section{Symbols and units:}

RuBP: ribulose-1,5-bisphosphate

RuBPCO: RuBP carboxylase/oxygenase

$P_{\mathrm{N}}\left[\mu \mathrm{mol} \mathrm{m} \mathrm{m}^{-2} \mathrm{~s}^{-1}\right]$ : net photosynthetic rate of leaf

$V_{\mathrm{c}}\left[\mu \mathrm{mol} \mathrm{m} \mathrm{m}^{-2} \mathrm{~s}^{-1}\right]$ : rate of carboxylation at RuBPCO

$V_{\mathrm{o}}\left[\mu \mathrm{mol} \mathrm{m} \mathrm{m}^{-2}\right]$ : rate of oxygenation at RuBPCO

$\tau$ : specifity factor for RuBPCO [7]

$C_{\mathrm{i}}[\mathrm{Pa}]$ : partial pressure of $\mathrm{CO}_{2}$ in the intercellular space

$O_{\mathrm{i}}[\mathrm{kPa}]$ : partial pressure of $\mathrm{O}_{2}$ in the intercellular space $\left(O_{\mathrm{i}}=30 \mathrm{kPa}\right)$

$R_{\text {day }}\left[\mu \mathrm{mol} \mathrm{m} \mathrm{m}^{-2} \mathrm{~s}^{-1}\right]$ : day respiration rate (excluding photorespiration) [1]

$W_{\mathrm{c}}\left[\mu \mathrm{mol} \mathrm{m} \mathrm{m}^{-2}\right]$ : RuBPCO (amount, activation state and kinetic properties) limited carboxylation rate

$W_{\mathrm{j}}\left[\mu \mathrm{mol} \mathrm{m} \mathrm{m}^{-2} \mathrm{~s}^{-1}\right]$ : RuBP regeneration-limited carboxylation rate

$T\left[\mu \mathrm{mol} \mathrm{m} \mathrm{m}^{-2} \mathrm{~s}^{-1}\right]$ : rate of phosphate release in triose phosphate utilisation (starch and sucrose production)

$W_{\mathrm{p}}\left[\mu \mathrm{mol} \mathrm{m} \mathrm{m}^{-2} \mathrm{~s}^{-1}\right]: T$-limited carboxylation rate $[4 ; 9]$

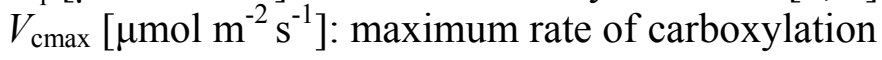


$K_{\mathrm{c}}\left[\mu \mathrm{mol} \mathrm{m} \mathrm{m}^{-2} \mathrm{~s}^{-1}\right]$ : Michaelis constant of $C_{\mathrm{i}}$ for carboxylation

$K_{\mathrm{o}}\left[\mu \mathrm{mol} \mathrm{m} \mathrm{s}^{-2} \mathrm{~s}^{-1}\right]$ : Michaelis constant of $O_{\mathrm{i}}$ for oxygenation

$J\left[\mu \mathrm{mol} \mathrm{m} \mathrm{m}^{-2} \mathrm{~s}^{-1}\right]$ : potential rate of electron transport [10]

$I\left[\mu \mathrm{mol} \mathrm{m} \mathrm{m}^{-2} \mathrm{~s}^{-1}\right]$ : quantum flux density absorbed by the leaf

$\alpha$ : efficiency of light energy conversion on an incident irradiance basis [mol(electron) $\mathrm{mol}^{-1}$ (photon)]

$J_{\max }\left[\mu \mathrm{mol} \mathrm{m} \mathrm{s}^{-1}\right]$ : radiation saturated rate of electron transport

$P_{\mathrm{N}}$ can be expressed by Farquhar model:

$$
P_{\mathrm{N}}=V_{\mathrm{c}}-0.5 V_{\mathrm{o}}-R_{\text {day }}=V_{\mathrm{c}}\left(1-\frac{0.5 O_{\mathrm{i}}}{\tau \cdot C_{\mathrm{i}}}\right)-R_{\text {day }},
$$

where the rate of carboxylation, $V_{\mathrm{c}}$, is assumed to be limited by one of three factors:

$$
\begin{aligned}
& V_{\mathrm{c}}=\min \left\{W_{\mathrm{c}}, W_{\mathrm{j}}, W_{\mathrm{p}}\right\} \\
& W_{\mathrm{c}}=\frac{V_{\mathrm{cmax}} \cdot C_{\mathrm{i}}}{C_{\mathrm{i}}+K_{\mathrm{c}}\left(1+O_{\mathrm{i}} / K_{\mathrm{o}}\right)},
\end{aligned}
$$

where the carboxylation is limited by the amount, activation state and kinetic properties of RuBPCO.

$$
W_{\mathrm{j}}=\frac{J \cdot C_{\mathrm{i}}}{4\left(C_{\mathrm{i}}+O_{\mathrm{i}} / \tau\right)}
$$

In the $W_{\mathrm{j}}$ formula above, it is assumed that four electrons generate sufficient STP and NADPH for the regeneration of RuBP in the Calvin cycle [2]. The radiation dependency in the model is on electron transport [10]:

$$
J=\frac{\alpha \cdot I}{\left(1+\frac{\alpha^{2} \cdot I^{2}}{J_{\text {max }}^{2}}\right)^{1 / 2}},
$$

and

$$
W_{\mathrm{p}}=3 T+0.5 V_{\mathrm{o}}=3 T+\frac{V_{\mathrm{c}} \cdot 0.5 O_{\mathrm{i}}}{C_{\mathrm{i}} \cdot \tau \cdot C_{\mathrm{i}} \cdot \tau}
$$

Temperature dependence of $K_{\mathrm{c},} K_{\mathrm{o}}, R_{\mathrm{d}}, \tau, J_{\mathrm{max}}, V_{\mathrm{cmax}}$, and $T$ are:

$$
\text { parameter }\left(K_{\mathrm{c},} K_{\mathrm{o}}, R_{\mathrm{d}}, \tau\right)=e^{c-\frac{\Delta H_{\mathrm{a}}}{R \cdot T_{\mathrm{k}}}}
$$

and

$$
\operatorname{parameter}\left(J_{\text {max }}, V_{\text {cmax }}, T\right)=\frac{e^{c-\frac{\Delta H_{\mathrm{a}}}{R \cdot T_{\mathrm{k}}}}}{1+e^{\frac{\Delta S \cdot T_{\mathrm{k}}-\Delta H_{\mathrm{d}}}{R \cdot \mathrm{T}_{\mathrm{k}}}}}
$$

[6], where $c$ is a scaling constant, $\Delta H_{\mathrm{a}}$ is an activation energy, $R$ is the gas constant $(R=$ $\left.0.00831 \mathrm{~kJ} \mathrm{~K}^{-1} \mathrm{~mol}^{-1}\right), T_{\mathrm{k}}$ is leaf temperature [K]. $\tau$ is a declining function of temperature whose activation energy is negative. $\Delta H_{\mathrm{d}}$ is the energy of deactivation, and $\Delta S$ is an entropy term. 